CAKRAWALA - Repositori IMWI | Volume 4, Nomor 1, April 2021

p-ISSN: 2620-8490; e-ISSN: 2620-8814

\title{
SISTEM ANALISIS KERUSAKAN SEPEDA MOTOR KARBURATOR DENGAN METODE FORWARD CHAINING
}

\author{
Zainil Abidin \\ Program Studi Sistem Informasi, Institut Manajemen Wiyata Indonesia \\ zainil.abidin@imwi.ac.id \\ Deni Erpian \\ Program Studi Sistem Informasi, Institut Manajemen Wiyata Indonesia \\ Denierpian84@gmail.com
}

\begin{abstract}
Motorcycles are said to be a means of land transfortation that is very popular with many people in the country but also in various parts of the world. In this era of advanced writers become writers on the rapid technology that is very rapid today, the author increasingly ideas for where in one program what is the application of motorcycle carburetor damage system de ngan forward chaining method or often called the application of expert applications into the quality of motorcycle service activities, especially in the workshop in a workshop. The author tried to modify an application that will be a lot of much loved sep eda motor to be able to easily get users more solutions from all solutions experienced by users. Applications that will design whether there is a carburetor motorcycle damage system by forward chaining and using basic visual tools as well as for modeling using UML (Unified Modeling Language) with microsoft access input database.
\end{abstract}

Keywords: forward chaining; expert system application; using visual basic 2010 with uml (integrated modeling language) tools

\section{Pendahuluan}

Pada masa sekarang ini, teknologi menjadi salah satu penunjang kebutuhan hidup manusia dalam bersosialisasi dengan lingkungan, teknologi dalam kehidupan manusia sangat bermanfaat dan membantu untuk mendapatkan suatu informasi yang akurat dan cepat .Dengan adanya teknologi menunjukkan bahwa semakin canggih segala bentuk sesuatu pekerjaan pada awalnya melakukan tenaga dan waktu yang sangat lama, dikarenakan dalam hal mencari informasi semakin sulit, kini menjadi pek erjaan yang mudah, dikarenakan mudah dalam mencari informasi karena disebabkan adanya teknologi. Sama halnya dengan kendaraan bermotor, semakin lama semakin jumlahnya terus bertambah. Hal ini disebabkan meningkatnya kebutuhan masyarakat akan kendaraan sebagai sarana transaportasi dari subsektor angkutan darat. Khusus pada Perusahaan yang bergerak di bidang pelayanan atau Service pada sepeda motor, Sistem Aplikasi Analisis Kerusakan Sepeda Motor Karburator merupakan salah satu sebagai penunjang kinerja pada Sistem yang sedang berjalan, dikarenakan sebagian besar orang dalam melakukan perbaikan atau sering disebut dengan Service kerusakan sepedamotor, hanya melakukan dengan insting manusia saja tanpa melihat panduan-panduan yang terstruktur dalam melakukan perbaikan pada sepeda motor, sehingga kesalahan-kesalahan dalam memperbaiki sepeda motor sering terjadi, oleh karena itu untuk membangun usaha, 
memerlukan peningkatan sistem kinerja atau teknologi sehingga faktor kesalahan dapat di minimalkan, langkah ini lah sangat perlu diperhatikan karena dengan melihat permasalahan kita dapat mencari solusi permasalahannya.

Dengan berbagai batasan masalah program ini mengidentifikasi kerusakan pada sepeda motor, dan memberi informasi berupa saran untuk mengatasi permas alahan yang dihadapi oleh pengguna dan metode inferensi Sistem Analisis Kerusakan Sepeda Motor Karburator yang dipakai menggunakan forward chaining dengan metode penelitian yang digunakan yaitu Research and Development Karena dalam hasil akhir daripenelitian ini adalah menghasilkan produk berupa software sistem analisis kerusakan sepeda motor karburator dengan metode forward chaining.

\section{Tinjauan Pustaka}

\section{Sistem Pakar}

Menurut Martin dan Oxman dalam buku Sistem Pakar Teori dan Aplikasi oleh (Kusrini, 2006) pakar adalah: "Sistem berbasis komputer yang menggunakan pengetahuan, fakta, dan teknik penalaran dalam memecahkan masalah yang biasanya hanya dapat dipecahkan oleh seorang pakar dalam bidang tersebut

a. Struktur Sistem Pakar

Sistem pakar teridiri -dari beberapa bagian pokok (Kusrini, 2006) yaitu:

1) Lingkungan Pengembangan

(Development Environment).

2) Lingkungan

Konsultasi

(Consultation Environment).

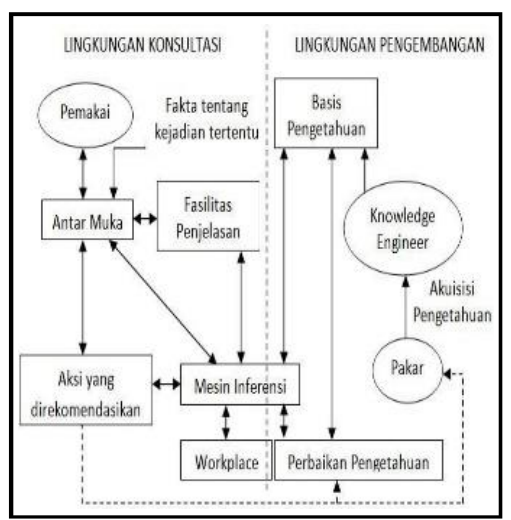

Gambar 1

Struktur sistem pakar

b. Faktor Kepastian

1) Ketidakpastian (Uncertainty)

Dalam menghadapi suatu masalah sering di temukan jawaban yang tidak memiliki kepastian penuh. Ketidakpastian ini dapat berupa probabilitas atau kebolehjadian yang tergantung dari hasil suatu kejadian. Hasil yang tidak pasti disebabkan oleh dua faktor, yaitu aturan yang tidak pasti dan jawaban pengguna yang tidak pasti atas suatu pertanyaan yang diajukan oleh sistem.

Sistem pakar harus mampu bekerja dalam ketidakpastian (Giarattano dan Riley, 1994). Sejumlah teori telah ditemukan untuk meyelesaikan ketidakpastian, termasuk diantaranya probabilitas klasik (classical probability), probabilitas Bayes (Bayesian probability), teori Hartley

berdasarkan himpunan klasik (Hartley theory based on classical sets), teori Shannon berdasarkan pada probabilitas (Shanon theory based on probability), teori Dempster -Shafer (DempsterShafer theory), teori fuzzy Zadeh (Zadeh's fuzzy theory), dan factor kepastian (certainty factor) 
(Suhendra; Ramdan Indra Bangun; et all., 2015).

2) Ketidakpastian Aturan

Ada tiga penyebab

ketidakpastian aturan, yaitu aturan tunggal, penyelesaian konflik, dan ketidakcocokan (incompatibility) Kesalahan dapat terjadi karena ambiguitas, sesuatu didefinisikan dengan lebih dari suatu cara, ketidaklengkapan data dan kesalahan informasi.

3) Pengertian Faktor Kepastian Faktor kepastian (certainty factor) diperkenalkan oleh Shortliffe Buchanan dalam pembuatan MYCIN (Wesley, 1984). Certainty factor (CF) merupakan nilai parameter klinis yang diberikan MYCIN untuk menunjukan besarnya kepercayaan.

\section{Metode Pengembangan Sistem}

Metode yang digunakan dalam pengembangan sistem adalah Model Waterfall. Waterfall merupakan model pengembangan perangkat lunak yang ada didalam model SDLC (Sequencial Development Life Cycle). Menurut Sukamto dan Salahuddin (2013:26) mengemukakan bahwa "SDLC atau Software Development Life Cycle atau sering disebut juga System Development Life Cycle adalah proses mengembangkan atau mengubah suatu sistem perangkat lunak dengan menggunakan model-model dan metodologi yang digunakan orang untuk mengembangkan sistem-sistem perangkat lunak sebelumnya, berdasarkan base practice atau caracara yang sudah teruji baik."

Metodologi yang digunakann object oriented dengan menggunakan
UML (Unified Modeling Language). UML adalah sebuah "bahasa" yang telah menjadi standar dalamindustri untuk visualisasi, merancang dan mendokumentasikan sistem piranti lunak dalam bahasa berorientasi objek seperti $\mathrm{C}++$, Java, atau VB. NET selain itu database yang digunakan adalah Microsoft access sebagai bahan pendukung lainnya (Edo Rizky Agusta, 2013).

\section{Basis Data}

Menurut James Martin dalam buku Pengantar Basis Data oleh (Widianti, 2009). Ba sis Data adalah "Suatu kumpulan data terhubung yang disimpan secara bersama-sama pada suatu media, tanpa adanya suatu kerangkapan data, sehingga mudah untuk digunakan kembali, dapat digunakan satu atau lebih progam aplikasi secara optimal, data disimpan tanpa mengalami ketergantungan pada program yang akan menggunakannya, data disimpan sedemikian rupa sehingga apabila ada penambahan, pengambilan dan modifikasi data dapat dilakukan dengan mudah dan terkontrol.

\section{Microsoft Access}

Microsoft Access adalah suatu program aplikasi basis data komputer relasional yang digunakan untuk merancang, membuat dan mengolah berbagai jenis data dengan kapasitas yang besar. Aplikasi ini menggunakan mesin basis data Microsoft Jet Database Engine, dan juga menggunakan tampilan graf is yang intuitif sehingga memudahkan pengguna.

\section{Metode Penelitian}

Metode Penelitian yang digunakan adalah metode penelitian dan 
pengembangan. Metode penelitian dan pengembangan atau dalam Bahasa inggris dikenal dengan sebutan Research and Development, Research and Development adalah metode penelitian yang dugunakan untuk menghasilkan produk tertentu dan menguji keefektifan produk tersebut supaya dapat berfungsi di masyarakat luas, maka diperlukan penelitian untuk menguji keefektifan produk tersebut (Edo Rizky Agusta, 2013).

Penelitian ini dilakukan di berbagai bengkel yang menyediakan pelayanan atau service pada sepeda motor di daerah kota sukabumi khusunya di jalan otista di kecamatan kebonjati.

\section{Hasil Penelitian dan Pembahasan}

\section{Analisis Masalah}

Sepeda motor sebagai sarana transportasi utama, banyak sebagian orang menggunakannya, baik muda ataupun tua dikarenakan sepeda motor merupakan transportasi yang mudah digunakan oleh semua kalangan. Namun demikian banyak pengendara sepeda motor yang tidak mengetahui kendala kerusakan yang dialami oleh sepeda motor tersebut.

Aplikasi yang akan dirancang ini akan membantu sebagian besar mekanik untuk mendiagnosa kerusakan yang terjadi pada sepeda motor karburator, sehingga mekanik mampu dapat menyelesaikan masalah mengenai kerusakan sepeda motor.

\section{Perancangan Sistem Perancangan Sistem}

Aplikasi analisis kerusakan sepeda motor karburator dibangun dengan bersifat object oriented atau berorientasi objek atau UML sebagai Bahasa pemodelan dan database Microsoft access sebagai bahan pendukung.

\section{Perancangan Aplikasi Perancangan menu aplikasi}

adalah tampilan atau gambaran dimana didalam aplikasi tersebut terdapat beberapa tools yang berbeda-beda dan memiliki tujuan tersendiri untuk mengeksekusi,

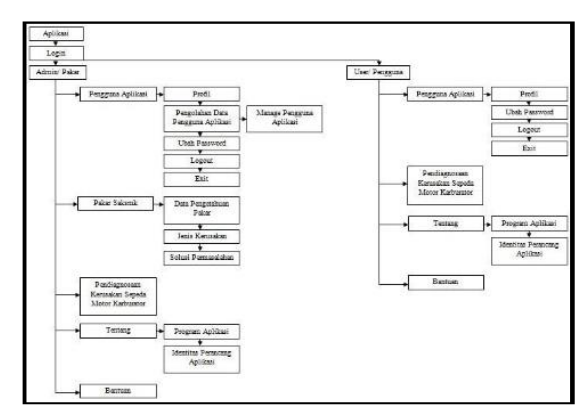

Gambar 2

Use Case Diagram Admin

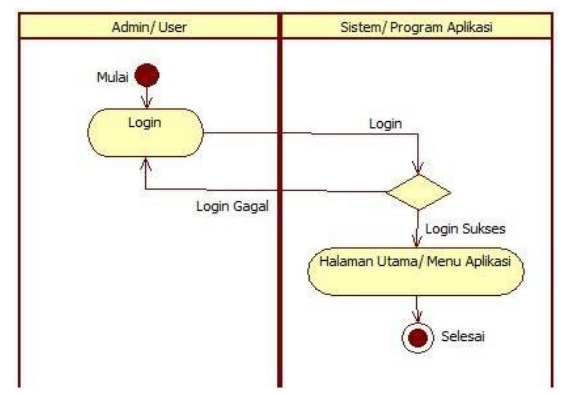

Gambar 3

\section{Use Case Diagram Admin}

Perancangan Aplikasi

Use Case adalah diagram yang menjelaskan mengenai aktor yang terlibat dengan perangkat lunak yang dibangun beserta proses-proses didalamnya.

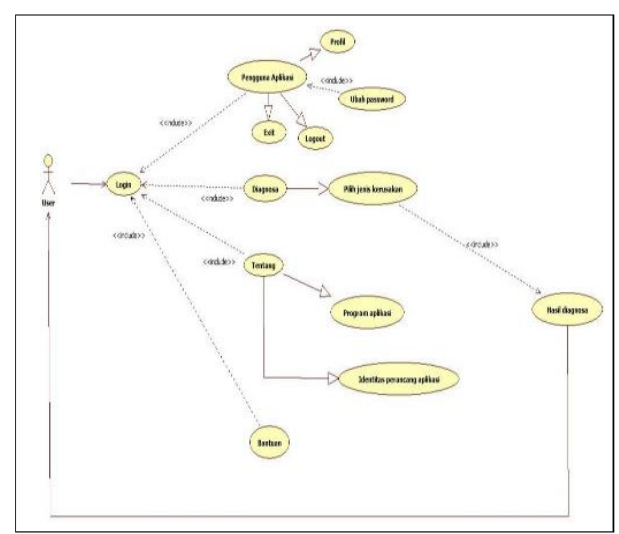

Gambar 4

Use Case Diagram User 


\section{Activity Diagram}

Activity diagram merupakan gambarkan proses bisnis dan urutan aktivitas dalam sebuah proses yang dipakai pada business modeling untuk memperlihatkan urutan aktifitas proses bisnis, struktur.

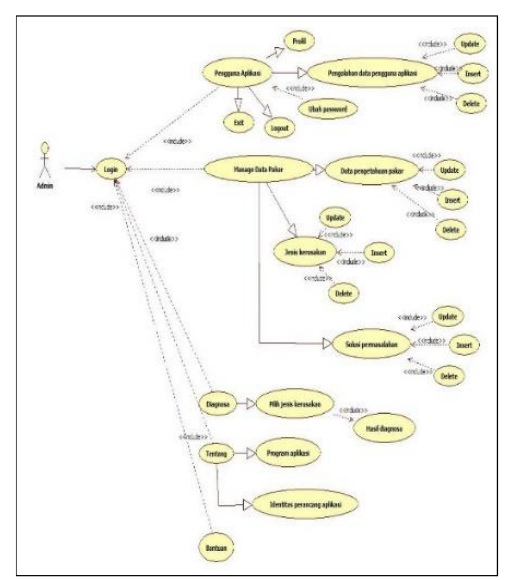

\section{Gambar 5}

\section{Activity Diagram Login}

Sequence Diagram Sequence diagram ini menggambarkan mengenai hubungan atau interaksi yang dilakukan oleh objek yang ada serta komunikasi yang dilakukan antar objek tersebut. menggambarkan struktur dan deskripsi class, package dan objek beserta hubungan satu sama lain seperti containment, pewarisan, asosiasi, dan lain -lain.

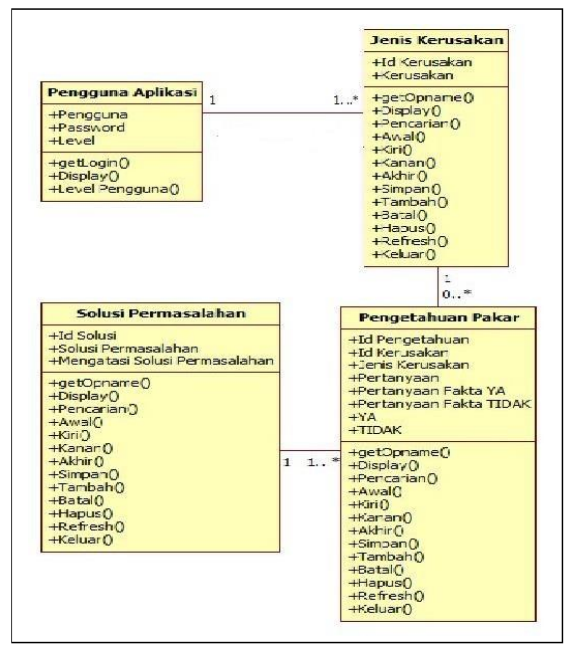

\section{Gambar 6}

Sequence Diagram Login

\section{Class Diagram}

Class adalah sebuah spesifikasi yang akan menghasilkan sebuah objek dan merupakan inti dari pengembangan dan desain berorientasi objek. Class diagram

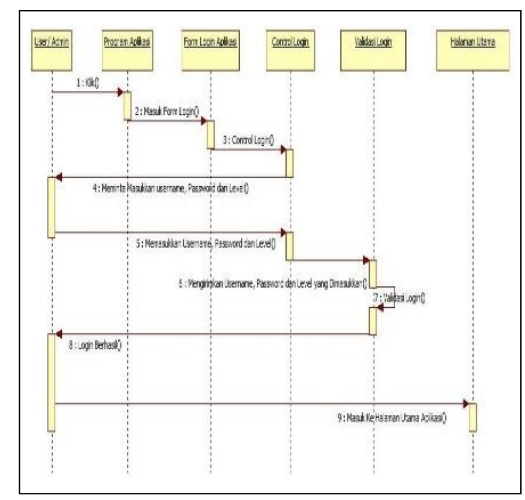

\section{Gambar 7}

Class Diagram

Gambar 7 merupakan bentuk dari salah satu model perancangan UML yang menjelaskan tentang table yang digunakan dalam perancangan aplikasi sistem analisis kerusakan sepeda motor karburator. Berikut table yang digunakan:

a. Tabel Pengguna Aplikasi Primary Key: Pengguna

Table 1

Tabel Pengguna Aplikasi

\begin{tabular}{cccc}
\hline Field & Type & Size & Keterangan \\
\hline Pengguna & Text & 50 & Pengguna \\
\hline Password & Text & 10 & Password \\
\hline Level & Text & 20 & Level \\
\hline
\end{tabular}

b. Tabel Jenis Kerusakan Primary Key: ID Kerusakan

Table 2

Tabel Jenis Kerusakan

\begin{tabular}{ccrc}
\hline Field & Type & Size & Keterangan \\
\hline ID Kerusakan & Text & 10 & ID_Kerusakan \\
\hline Kerusakan & text & 225 & Kerusakan \\
\hline
\end{tabular}


c. Tabel Pengetahuan Pakar Primary

Key: ID Pe ngetahuan

Table 3

Tabel Pengetahuan Pakar

\begin{tabular}{llll}
\hline \multicolumn{1}{c}{ Field } & Type & Size & Keterangan \\
\hline ID Pengetahuan & Text & 10 & ID_Pengetahuan \\
\hline ID Kerusakan & Text & 10 & ID_Kerusakan \\
\hline Jenis Kerusakan & Text & 225 & Jenis_Kerusakan \\
\hline Pertanyaan & Text & 225 & Pertanyaan \\
\hline Pertanyaan Fakta Ya & Text & 225 & Pertanyaan Fakta_Ya \\
\hline Pertanyaan Fakta Tidak & Text & 225 & Pertanyaan Fakta_Tidak \\
\hline Ya & Text & 10 & Ya \\
\hline Tidak & Text & 10 & Tidak \\
\hline
\end{tabular}

d. Tabel Solusi Permasalahan Primary

Key: ID Solusi

Table 4

Tabel Solusi Permasalahan

\begin{tabular}{lccl}
\hline \multicolumn{1}{c}{ Field } & Type & Size & Keterangan \\
\hline ID Solusi & Text & 10 & ID_Solusi \\
\hline Solusi Permasalahan & Text & 10 & $\begin{array}{l}\text { Solusi } \\
\text { Permasala han }\end{array}$ \\
\hline $\begin{array}{l}\text { Mengatasi Solusi } \\
\text { Permasalahan }\end{array}$ & Text & 225 & $\begin{array}{l}\text { Mengatasi_ } \\
\text { Solusi_Per } \\
\text { masalahan }\end{array}$ \\
\hline
\end{tabular}

\section{Implementasi}

a. Persiapan Intalasi Perangkat Lunak Instalasi ini merupakan langkah awal dalam pembuatan sistem analisis kerusakan sepeda motor karburator atau sebagai bahan utama dalam perancangan sistem, aplikasi yang diinstal diantaranya adalah: Visual Basic 2010, Microsoft Office 2007 dan StartUML.

b. Evaluasi Sistem Perangkat Lunak (Program) dan Evaluasi

Perancangan Sistem Evaluasi ini sebagai bahan atau langkah selanjutnya dalam perancangan sistem analisis kerusakan sepeda motor karburator untuk menghindari kesalahan atau error pada program yang tengah dijalankan, baik dari penulisan, aplikasi dan logika yang digunakan dalam perancangan program aplikasi itu sendiri.

c. Implementasi Antarmuka dan Penggunaan Program Aplikasi.

Pada tahap atau bagian implementasi rancangan antar muka ini merupakan bagian yang menyediakan sarana untuk pemakai agar bisa berkomunikasi dengan sistem dalam bentuk pr ogram aplikasi yang akan dijelaskan secara singkat dan jelas mulai dari awal sampai akhir penggunaan program aplikasi sistem analisis kerusakan sepeda 
motor karburator beserta

cara penggunaanya.

1. Tampilan Startup Program

Tampilan startup adalah tampilan yang pertama kali akan ditampilkan ketika membuka program aplikasi.

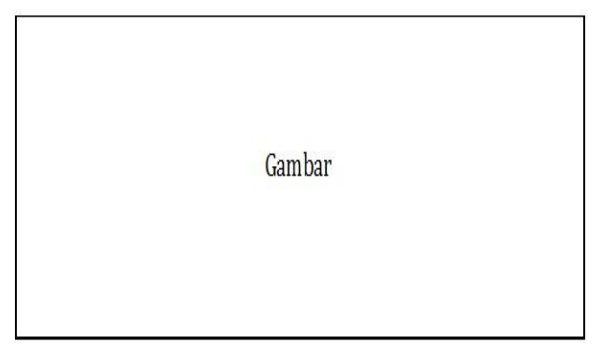

\section{Gambar 8}

tampilan startup program

2. Tampilan Login Program Halaman login adalah halaman yang akan ditampilkan setelah tampilan startup selesai pada program aplikasi.

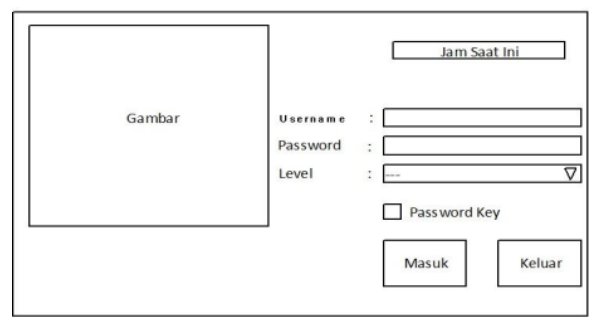

Gambar 9

tampilan Login program

3. Tampilan Progress Bar Program

Tampilan progress bar adalah tampilan dimana proses login terlewati dengan benar.

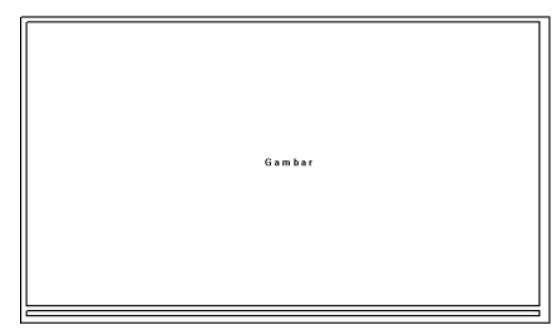

Gambar 10 tampilan progress bar program
4. Tampilan Halaman Utama

Tampilan halaman utama merupakan tampilan untuk masuk ke menu sistem jika berhasil melakukan login.

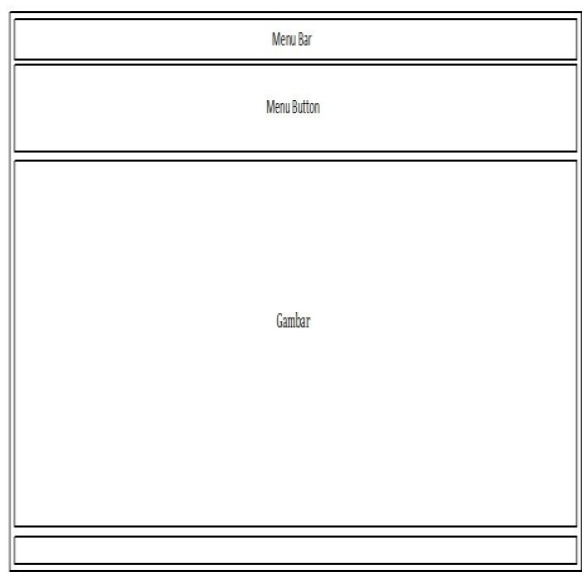

\section{Gambar 11}

tampilan halaman

utama

5. Tampilan Pengolahan Data Pengguna

Tampilan ini bertujuan untuk pengolahan data pengguna aplikasi pada saat melakukan penambahan data pengguna.

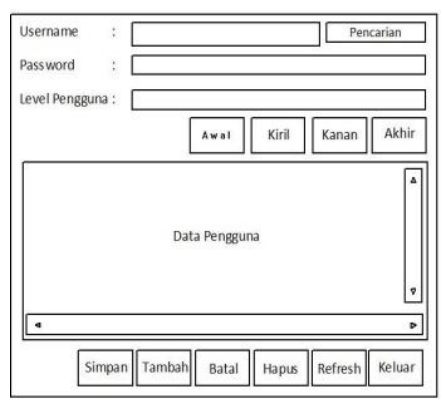

Gambar 12

Contoh tampilan pengolahan data pengguna aplikasi

6. Tampilan Data Pengetahuan Pakar Tampilan pengetahuan ini adalah tampilan yang dimana peran sebagai pakar atau admin pada sistem analasis kerusakan sepeda motor karburator melakukan analisis mengenai kerusakan-kerusakan pada sepeda motor. 


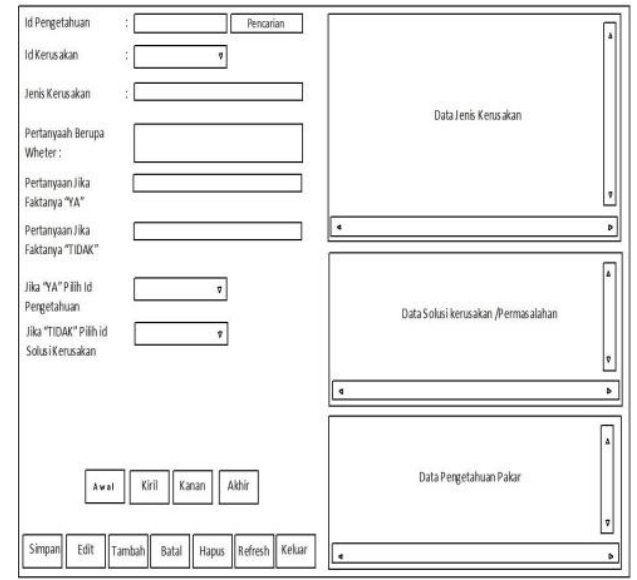

Gambar 13

Contoh tampilan data pengetahuan pakar

7. Tampilan Jenis Kerusakan

Tampilan jenis kerusakan adalah tampilan yang dimana peran sebagai pakar atau admin melakukan inputan pada sistem analasis kerusakan sepeda motor karburator mengenai kerusakankerusakan.

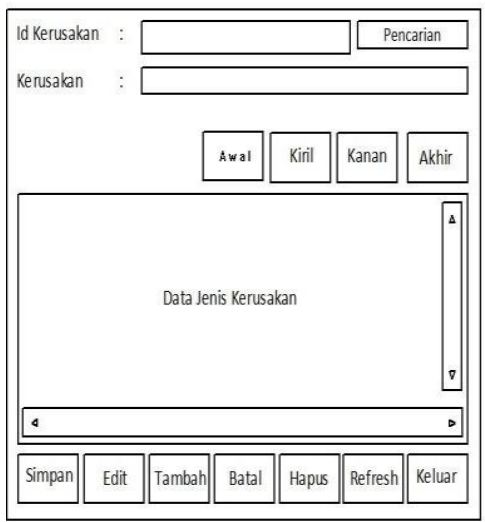

\section{Gambar 14}

Contoh tampilan jenis kerusakan

8. Tampilan Solusi Kerusakan Tampilan solusi kerusakan ini bertujuan atau berfungsi sebagai halaman dimana pemberi solusi dari permasalahanpermasalahan yang dimasukan sebelumnya.

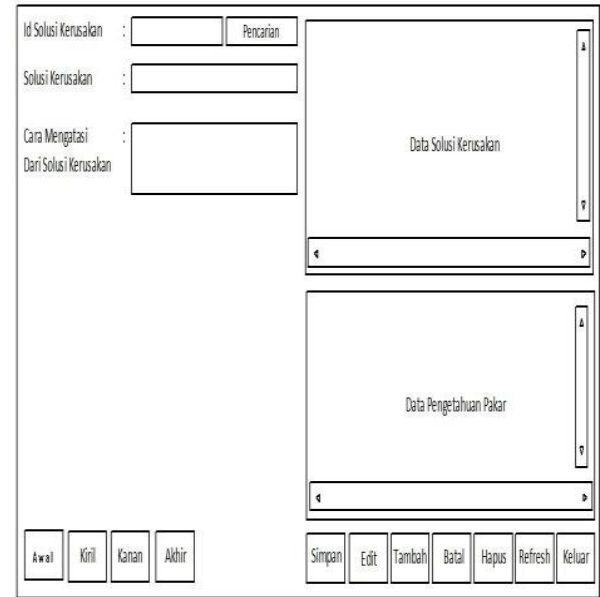

Gambar 15

Contoh tampilan solusi kerusakan

9. Tampilan Diagnosa Tampilan diagnosa adalah tampilan yang dimana berperan sebagai halaman untuk memulainya menganalisis kerusakan yang dihadapi oleh user atau pengguna aplikasi.

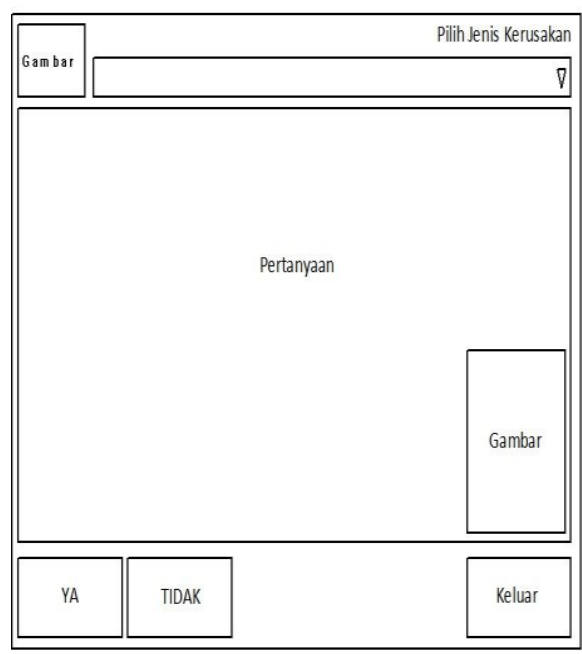

Gambar 16

Contoh tampilan diagnosa

10. Contoh Tampilan Solusi dan Cara Mengatasi Permasalahan Pada Halaman Diagnosa. 


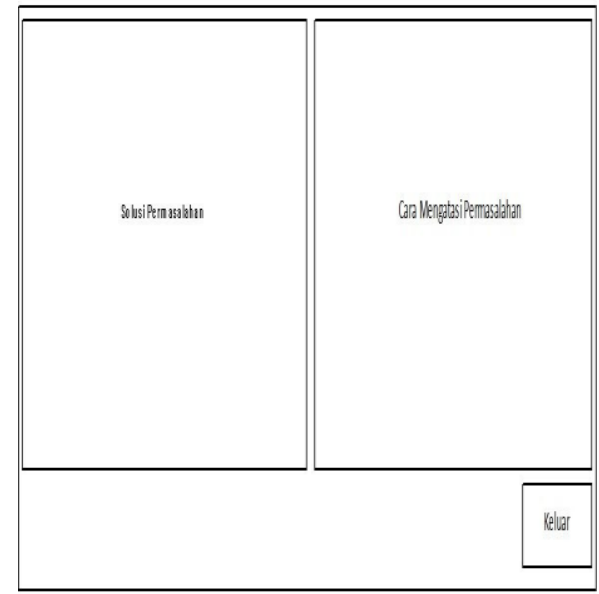

Gambar 17

Contoh Tampilan Solusi dan

Cara Mengatasi Permasalaha $\mathrm{n}$ Pada Halaman Diagnosa.

\section{Pengujian Kualitas Instrumen}

1. Pengujian,

Pengujian merupakan tujuan untuk menja min bahwa perangkat lunak yang dibangun memiliki kualitas yang baik, Pengujian dilakukan untuk mengetahui kelemahan dari perangakat lunak itu sendiri dan mampu untuk merepresentasikan kajian pokok dari spesifikasi, analisis, perancangan dan pengkodean dari perangkat lunak. Pengujian perangkat lunak ini menggunakan metode pengujian

2. Black box testing.

Black box testing adalah pengujian yang dilakukan hanya mengamati hasil eksekusi melalui data uji dan memeriksa fungsional dari perangkat lunak, black box testing dilakukan dengan cara menguji aplikasi dengan memasukkan data ke dalam formform yang telah disediakan.

3. Rencana Pengujian

Rencana pengujian yang akan dilakukan dengan menguji secara alpha menggunakan metode black box dalam pengujian sistem analisis kerusakan sepeda motor karburator secara keseluruhan.

\section{Simpulan}

1. Aplikasi yang dibuat dapat membantu mempermudah pengguna atau user atas izin admin untuk mencari informasi mengenai kerusakan-kerusakan sepeda motor karburator dengan cepat dan mudah tanpa harus menanyakan terlebih dahulu untuk konsultasi kepada orang lain.

2. Aplikasi dibuat dengan cara penyajian yang terdiri dari jenis kerusakan, data pengetahuan pakar dan solusi kerusakan atau permasalahan.

3. Penerapan metode sistem berbasis aturan de ngan proses inferensi forward chaining dalam aplikasi analisis kerusakan sepeda motor kerburator.

\section{Saran}

\section{Saran Teoritis}

a. Program ini masih jauh dari sempurna, oleh karena itu perlu dilakukan perbaikan -perbaikan dalam aplikasi analisis kerusakan sepeda motor kerburator demi kesempurnaan.

b. Jenis kerusakan, data pengetahuan pakar dan solusi kerusakan atau permasalahan yang terdapat dalam aplikasi analisis kerusakan sepeda motor kerburator jumlahnya sedikit dan sangat perlu untuk dapat ditambahkan lebih banyak lagi, sehingga informasi yang dimiliki akan semakin luas dan banyak.

c. Perawatan dan evaluasi terhadap sistem perlu dilakukan agar program aplikasi analisis kerusakan sepeda motor kerburator dapat digunakan dengan baik dan maksimal. 
2. Saran Praktis

a. Program aplikasi analisis kerusakan sepeda motor karburator perlu di miliki oleh setiap jasa pelayanan khususnya bengkel sepeda motor untuk dapat di manfaatkan oleh mekanik -mekanik.

b. Program aplikasi analisis kerusakan sepeda motor karburator dapat dijadikan bahan untuk dapat mempertajam ilmu. Kotler dan Armstrong (2015) menyatakan bahwa pemasaran sebagai proses di mana perusahaan menciptakan nilai bagi pelanggan dan membangun pelanggan yang kuat relationship untuk menangkap nilai dari pelanggan sebagai imbalan. Maka setiap produsen baik jasa maupun produk harus selalu mampu menciptakan nilai dalam jasa atau produk mereka sehingga menimbulkan

ketertarikan

pelanggan.

\section{Daftar Pustaka}

Edo Rizky Agusta. (2013). Sistem Informasi Pemesanan Tiket Bus Pada PO Nusantara Cabang Semarang Dengan Framework Phonegap. Fakultas Ilmu Komputer.

Kusrini. (2006). Sistem Pakar Teori dan Aplikasi. Andi.

Suhendra; Ramdan Indra Bangun; et all. (2015). Sistem Pakar Diagnosa Gangguan Sambungan Telepon. Semnasteknomedia Online.

Widianti, S. (2009). Pengantar Basis Data. Penerbit Fajar. 